\title{
ALS Curriculum Implementation for Juvenile Delinquents in Urban and Rural Areas in the Philippines: A Comparative Analysis
}

\author{
Vandon T. Borela ${ }^{1}$ \\ ${ }^{1}$ Master's Candidate, Curriculum and Instruction, Philippine Normal University, Philippines
}

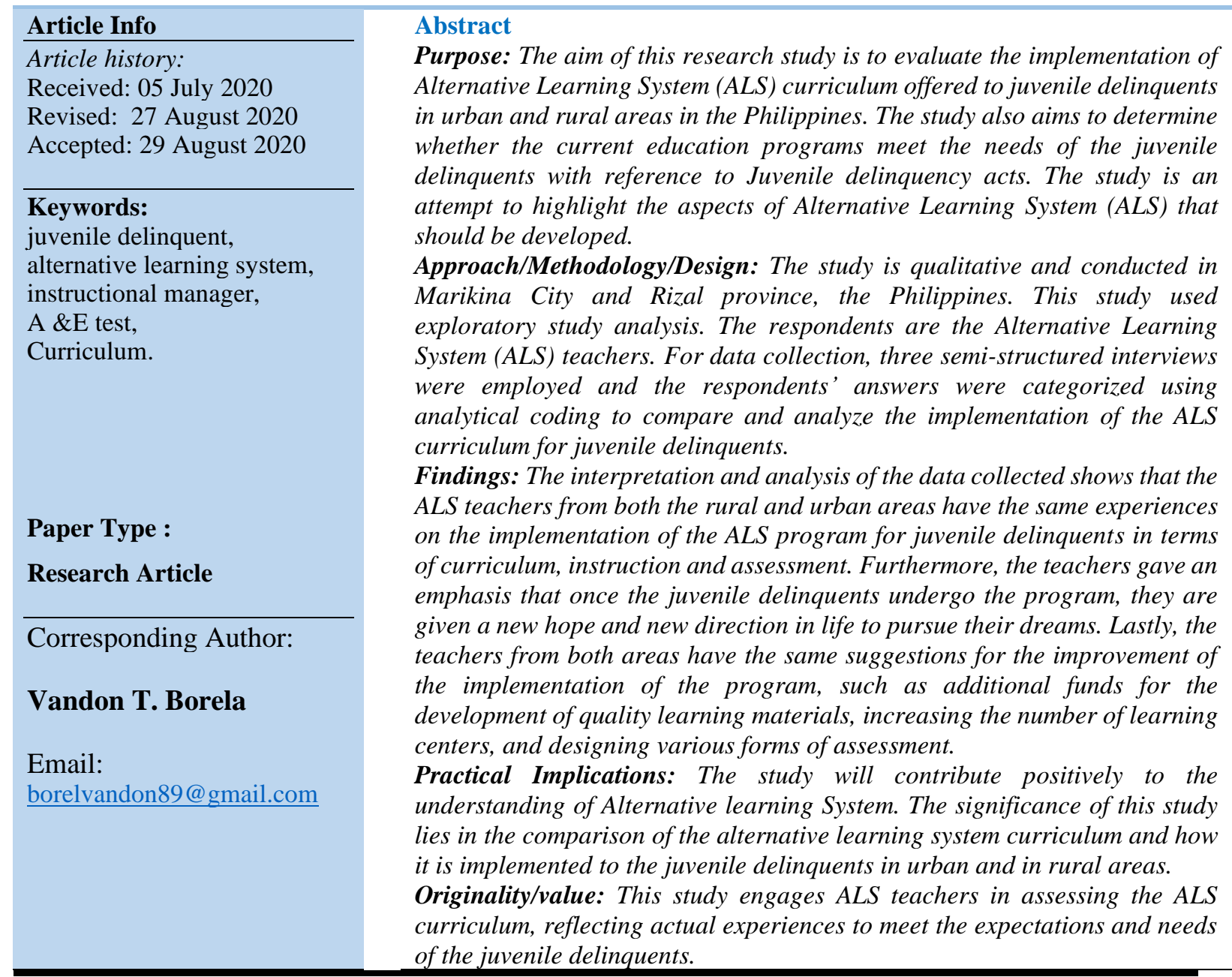

\section{Introduction}

Education plays a major role on the nation building. It prepares the young generation to become worthy citizens. The curriculum leaders in the Philippines continuously refine the curriculum based on the needs of the learners and interests of the nation. Being young citizens below 18 years old and subjected to infractions, education helps the juvenile 
delinquents to redeem themselves. Thus, it is best to trace the source of an educational system such as the ALS to the basic and fundamental law of the land. The Philippine Constitution stipulates that elementary education is free and compulsory, and free secondary education through the Department of Education (DepEd). This means that all Filipinos have a constitutional right to basic education, and the DepEd is mandated to provide this service to all Filipinos. In the 80's, the global community launched a campaign called Education for All (EFA) that aimed to eradicate illiteracy and promote functional literacy for all peoples of the world (Guerrero 2006).

In the present day, new goals are set by United Nations and its member countries known as Sustainable Development Goals wherein education is one of the priorities. Obtaining a quality education is the foundation to improve people's lives and attain sustainable development (Byun et al., 2018). Through education, the juvenile delinquents are given an equal opportunity which is also one of the goals of the Sustainable development goal in 2017. The Philippines was a signatory to this, and as such, the country is committed to providing education for all Filipinos. Against this backdrop, the Philippine government put in place the following legal measures and commitment that serve as basis for the introduction of ALS in the Philippine educational system. Firstly, the Republic Act 9155 named as The Governance Act of Basic Education. On June 6, 2001, the Philippine Congress passed a law that defined the governance of basic education. Among many of its provisions, this law recognized the ALS as a complement of formal education and a major component of basic education with a clearly defined role within the overall educational goals. Secondly, the Executive Order No. 356 renamed the Bureau of Non-formal Education (BNFE) to the Bureau of Alternative Learning System (BALS). These laws have a impact on the recognition of non-formal education in the country.

On September 13, 2004, the Office of the President of the Republic of the Philippines renamed the DepEd's Bureau of Non-formal Education to the Bureau of Alternative Learning System (BALS) through an Executive Order signed by President Gloria Macapagal-Arroyo. Not only does this Order reiterate the Bureau's mandate to address the learning needs of marginalized learners but also directs BALS to provide a systematic and flexible approach to reach all types of learners outside the school system. In addition, the Executive Order spelled out the functions of the BALS. They include the following; to address the learning needs of all marginalized groups including the deprived, depressed and underserved citizens, to coordinate with various agencies for skills development of the learners, to expand access to educational opportunities for citizens of different interests, capabilities, demographic characteristics, and socioeconomic origins and status, to promote certification and accreditation for basic education of alternative learning programs both non-formal and informal in nature.

\section{Literature Review}

The hope of any nation lies in the young generations but due to many circumstances sometimes the youngsters commit certain criminal offenses like theft, sniffing of glue or solvents, vagrancy and violation of curfew hours, (UNICEF 2003), simple assault or battery, possessions of marijuana, drug paraphernalia, stolen property, and weapon, harassment, fraud, traffic violations, criminal trespass, mischief/criminal nuisance, resisting an officer without violence 
(Global Youth Justice Org 2015). Youngsters committing and indulging in such acts are categorized as juvenile delinquent. Not so long ago, the juvenile delinquents were treated in the same manner with the adult offenders. Many reports showed that once the juvenile delinquents are detained together with the adult offenders, they are sexually harassed and abused (UNICEF 2003). Because of this mistreatment, the United Nations created two policies that give protection to the juvenile delinquents. One of this two rules is the "United Nations Standard Minimum Rules in Administration of Juvenile Justice" also known as Beijing rules. One of the provisions of this rule is, while the juvenile delinquent is in the custody of the government, they shall receive care, protection and all necessary individual assistance-social, educational, vocational, psychological, medical and physical-that they may require in view of their age, sex and personality (U.N. 2006). The second law is the "United Nations Guidelines for the Prevention of Juvenile Delinquency" also known as the Riyadh Guidelines. It states that educational systems should extend particular care and attention to young persons who are at social risk. Specialized prevention programmes and educational materials, curricula, approaches and tools should be developed and fully utilized (CRIN ORG1990). The two provisions mentioned in the international laws lead the Philippine law makers to come up with Republic Act number 9344, also known as Juvenile Justice and Welfare Act. According to this law, it shall cover the different stages involving children at risk and children in conflict, ensuring prevention and providing rehabilitation and reintegration. This law was strengthened by Republic Act number 10630 which is also known as Strengthening the Juvenile Justice System. According to this act, every municipality shall establish a "bahay-kalinga" for the juvenile law offenders and it is funded by the national and local government unit (GOV. PH). The two laws mentioned reiterated the role and the importance of education in giving intervention and in reintegration of the juvenile delinquents.

The Philippine education system is currently undergoing changes and moving towards K-12 curriculum. Alternative Learning System (ALS) was established to provide all Filipinos the chance to have access and complete their basic education in a way that fits their distinct situations and needs. As a parallel learning system, ALS consists of Informal Education and Non-Formal Education, the latter being comprised of the Basic Literacy Program (BLP) and the Accreditation and Equivalency Program (A\&E). Adults, OOSYs, and OOSCs who cannot read and write can learn under BLP. Meanwhile, learners 15 years old and above who can read and write but have not completed basic education can continue elementary or secondary schooling through A\&E (DepEd, 2016).

ALS Learners receive education for free and benefit from five learning strands based on the definition of functional literacy: communication; problem solving and critical thinking; sustainable use of resources and productivity; development of self and sense of community; and expanding one's world vision (DepEd, 2016). As much as 16.59 million Filipinos now have better opportunity for employment and livelihood as the Department of Education (DepEd) is working double-time to revive and expand the coverage of the Alternative Learning System (ALS). The figure, which translates to 39.03 percent or two-fifths of the entire labour force, is based on the Philippine Statistics Authority's (PSA) data on working Filipinos who have not completed basic education as of April 2016 (DepEd, 2016). And it is a common knowledge that educational attainment is directly related to the kind of life he or she will make. 
Pilar (2015) conducted a study to investigate the lived experiences among the alternative learning students (ALS) in Bacolod City, Philippines. It conceptualized that education can be flexible according to the needs of the learners, thus, education can take place beyond borders. It is recommended that the ALS students' performance and development should be monitored so that they will be ready to take the ALS accreditation and equivalency test. Therefore, these ALS students need to be provided with quality education beyond classroom.

Bantulo(2016) in his study examines the experiences of Alternative Learning System (ALS) learners in their pursuit to education, their coping mechanisms on the challenges in their educational pursuit and their dreams and aspirations in life. This study recommended further research exploring the parameters of the ALS teachers and highlighting their personal experiences and the challenges that they face in implementing the ALS program in the far flung schools. Hence, it may be useful and coherent to see the program from different perspective. In addition, Atillano, et al. (2016) discussed that instructional managers should look into the factors contributing to the learning motivation of the ALS learners in involving themselves in school or any instructional program. Alternative Learning System providers should also revisit and review the programs and balance out the relationship of the learners' ability and the appropriateness, complexity and demands of the tasks given to them as the relationship of these factors are crucial in bridging the willingness of the learners needed for a successful achievement outcome.

In his article, Castolo, et al. (2016) presents an assessment framework on how the Alternative Learning System can best sustain its value and worth to achieve education for all in the Philippines. The results of this study provide insights in the determination of the unmet needs of the learners and put to surface whether ALS intervention is sufficiently intensive to achieve desired goals for the out of school youth. Moreover, the findings suggest that educational inputs along with its processes have a statistical significant relationship with all its result and the challenges in the implementation of the program. Another study was conducted by Mercado (2015), examining the problems encountered in the Alternative Learning System in Tanauan City. The researcher tried to determine the possible problems that the students encounter or experience in their schools. The results were then used to discuss the implications in the implementation of Alternative Learning System in the city.

Apao, et al. (2014) conducted a study to assess the implementation of the alternative learning system program along the provision of life skills, increased literacy and quality of living. The Alternative Learning System A\&E program was effective in cultivating life skills of the recipients. The program improved the quality of living of the respondents as they continue their pursuit for meaning and significance in life. It proved that students still learn and acquire the life-long competencies even outside the walls of the formal school system. The alternative learning system was an option for those who wanted to improve their quality of living and rise beyond poverty. In addition, Baywong et al. (2011) measured the existing stakeholders' perception of the strengths and weaknesses of the social services offered by the government to the Out-of-school Youth. The study aimed to identify the problems or challenges experienced by the learners while enrolled in the Alternative Learning System (ALS) program and lastly, to identify self-discoveries of the learners that lead to self-realizations for the betterment of 
their economic, social and cultural conditions. The results of the study would contribute to improve the effectiveness and efficiency of the instructional delivery system of the Alternative Learning System towards the students. It also aimed to promote learning opportunities for the students and to improve instruction qualities for the students. The results of the study reveal that the respondents realize that there is minimal support for the entire implementation of the Alternative Learning System (ALS) Program.

Based on this review of literature, it is evident that the ALS program is perceived to have provided full support to the learners in its main objective on the instruction and education of the respondents. However, the previous studies indicated that there is moderate support from government in terms of facilities, equipment and the publishing and printing of bulletins. In addition, slight support was received for social integration of the learners and facilitation of parent's forum. According to the learners, they received no support for income generation, medical health and provisions for day care centres that are not the major components of the ALS implementation. The challenges and problems encountered by the learners while enrolled at the Alternative Learning System Centre are financial problems, restricting and limiting the achievement rates of both the learners and the implementers. The slightly severe problems encountered by the learners are their personal, family and peer relations problems, the lack of government supplementary support, and methods of teaching in the school. Generally, all of the learners believe that the ALS education shall aid them in their competency for a college education or for employment opportunities in the future.

\section{Conceptual Framework:}

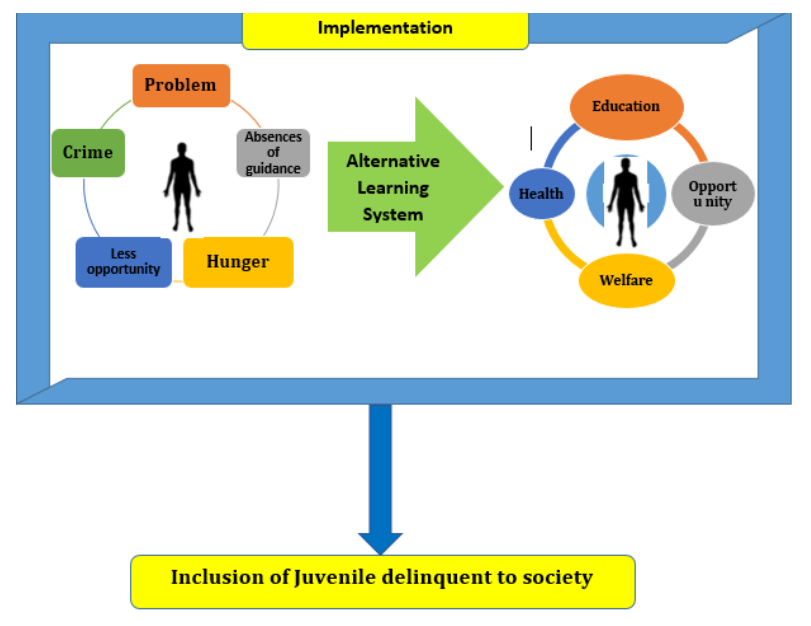

Figure 1: Conceptual Framework of the Study

Figure 1 shows the conceptual framework of the study. The alternative learning system is a powerful tool to change the life of juvenile delinquents. Through ALS, they are given a chance to education, to have good health, good welfare and equal opportunity. The implementation of the said education program will be examined using the qualitative research methods.

\section{Methodology and Procedures}


This research study aims to investigate the implementation of alternative learning system in urban and rural areas using qualitative research methods. According to Cresswell (2003) a qualitative study is defined as an inquiry process of understanding a social or human problem, based on building a complex, holistic picture, formed with words, reporting detailed views of informants, and conducted in a natural setting. The exploratory research design was adopted because it is a powerful tool in getting a clear understanding of experiences and gaining insights into the topic under investigation. According to Carr \& Worth (2001), phone interview allows interpersonal communication without a face-to-face meeting and it is a cost effective alternative. The respondent's answers were transcribed and categorized using analytical coding (Richards 2005) to compare and analyse the implementation of the ALS curriculum for juvenile delinquents.

The study is based on semi-structured interviews. The interview guide questions were developed based on the objectives of the study and gaps identified in the literature review. Three questions were used to elaborate on the implementation of alternative learning system for juvenile delinquents. The first question focuses on the teachers' experience on the implementation of alternative learning system in terms of curriculum, instructions, and assessment. The second question elaborates on the benefits of the alternative learning system to the juvenile delinquents. The last question unfolds certain suggestions for the instructional managers to improve the implementation of alternative learning system to effectively cater the juvenile delinquents. The participants in this study consisted of 8 instructional managers from an urban area and a rural area. Table 1 shows the background of the respondents.

Table 1: Background Data of the Respondents

\begin{tabular}{|l|l|l|}
\hline Characteristics & & Teacher's number \\
\hline Gender & Male & 2 \\
Female & 4 \\
& LGBTQ & 2 \\
& $\begin{array}{l}\text { 30-35 years } \\
\text { 36-40 years } \\
\text { 41 and above }\end{array}$ & 2 \\
Experience & $\begin{array}{l}\text { 5-10 years } \\
\text { 11-15 years } \\
\text { 16-20 years }\end{array}$ & 1 \\
Educational & $\begin{array}{l}\text { Bachelor's } \\
\text { attainment }\end{array}$ & 15 \\
& $\begin{array}{l}\text { Master's degree } \\
\text { Alegree }\end{array}$ & 3 \\
\hline
\end{tabular}

\section{Results and Discussion}


The data obtained from the respondents is analyzed in this section. The results are also discussed and presented in relation to the aims of the study. The responses to the semistructured questions of the interview are analyzed and discussed one by one.

1. How is the current ALS program implemented in terms of: a. Curriculum, b. Instruction, c. Assessment?

On the phone interviews, the participants described the implementation of alternative learning system in terms of a). curriculum, b). instruction and c). assessment. They described the curriculum of the alternative learning system as 'properly aligned with the K to 12 curriculum'. As the Philippine government changed the education system, the government also changed the curriculum of the alternative learning system.

More specifically, a respondent from urban area described the (a) curriculum for alternative learning system;

"meron ding mga set of knowledge, skills and competencies nadapatmadevelopsamgaestudyante after nilaumattend ng series of classes."

while a respondent from rural area said that;

"Sa kasalukuyan ang ALS po ay naka-align narinsabagongkurikulumnaipapatupad ng

DepEd yun ay ang K-12, kung saanlahat ng mgadapatmatutunan ng learners ay guided ng curriculum guide”.

Based on the responses to the interview, all of the eight respondents have the same views on how the alternative learning system is implemented in terms of curriculum. The statements of the respondents indicate that the curriculum of alternative learning system is based on the $\mathrm{K}$ to 12 curriculum wherein Department of Education designed the K-12 curriculum and they also changed the curriculum of the alternative learning system. Hence, there are prescribed competencies that should be developed by the learners (DepEd). In terms of (b) instruction in alternative learning system, the respondents reported that in alternative learning centres they have the freedom on how they teach the competencies. Accordingly, there is no prescribed method for teaching or delivery of the lessons. The statement of a respondent from the urban area reflects that;

"malayakamingmga ALS teacher kung paanonaminituturo ang mga topic at paano kami magtuturosamga students";

and a statement of a respondent from rural area;

"maaringmodyular kung ang learner ay hindimakapasoksaitinakdangaraw ng pasokpwederin through internet kungm ay computer at internet connection ang learner".

The respondents have a unison answer on how the instruction is done in alternative learning system. But the most remarkable statement is given by a respondent from the urban area. It is very significant for the present study;

"Nagtututro pa rinnaman ang guro o IM's pero mas binibigyangpagppahalaganamganaituturo ay mai-apply ng learner satotoongbuhay”. 
It shows that the instructional managers or the ALS teachers give more emphasis on teaching the life skills which are necessary and important to the lives of the learners. The life skills refer to the defined psychosocial abilities for adaptive and positive behaviour that enable individuals to deal effectively with the demands and challenges of everyday life. Life skills are necessary to the juvenile delinquents to enable them to cope up with the difficulties and survive on the rapid changes that take place in the society (UNICEF.org).

In terms of (c) assessment, the respondents from both areas indicated that there is only one assessment given to the learners which is the A \& E Test. It is taken by the learners once they are done with the program. This is proven by the statements from the respondent form urban area;

"Walangbinibigayna test ang guro o IM nakagayasa Formal school, bukod tanging A \& E paper and pencil test nabigay ng DepEd ang magpapatunaysapag-aaral at pagnakapasa ang learners bibigyansila ng certificate napatunaynapasado at taposnasila." and the statement from the rural area; "Pag nataposna ang mga learners sa program magte-take sila ng A \& E Test kung saantitingnan at susukatin ang pakatuto ng learners usually lahatyan provided na ng DepEd at pagpasado ang learner ditto sa Division naming may program kami, graduation program para maramdamantlaaga ng mga learner nanagbungayungpagsisikapnila."

The ALS generally makes use of end-of-program tests which may be given at any time when a learner completes the program. The A\&E tests measure the functional literacy competencies, such as communicating effectively, solving problems scientifically, thinking creatively and critically, using resources sustainably and productively, developing one's self, nurturing a sense of community, and expanding one's world view (Guerrero 2004). Assessment plays a vital role on the learning process. It provides feedback on the effectiveness of instruction and gives students a measure of their progress (Jabbarifar, 2009).

2. How can the juvenile delinquent benefit from ALS curriculum?

Based on the data collected from the respondents, the alternative learning system helps the juvenile delinquents in various ways. First, through ALS, the juvenile delinquents as learners feel that they are accepted by the community wherein the instructional managers set a welcoming environment. The juvenile delinquents feel that they are comfortable and will not be judged because of what they have done from the past. A respondent from urban area stated that;

"Sir suggestion ko lang ha, bakapwedenggumamit ka ng ibang term sa study mo, Wag monggamitinyung term mona juvenile delinquent kasipagnarinigyan ng mga students sa ALS magiiba ang tinginnilasasarilinila. Pag anditosilasa ALS classes namin, we set the mood na gusto naming maramdaman ng mga students naming natanggapsila at higitsalahat may pag-asasila."

Setting a welcoming environment starts from the words used by the instructional managers instead of labelling or calling the juvenile delinquents as a delinquent learners. Using other words, for instance "love child', grants the juvenile delinquents a feeling that they are given a new chance and hope in life. The respondents from the rural area said that; 
"Ay napakalakingtulongtalaga $n g$ ALS samgakabataanlalonasamganaligaw at gustongmakapagbago."

"tutulungannatinmgaguronamagkarronmuli ng bagong direction yungbuhaynila, at dilang direction magandang direction."

"dahilsa ALS nakatapos at nakapagsimulaulitsilamangarapnamaabot ang pangarapnila."

In this event the instructional manager does not only function as a teacher but also as a parent, a family, and a friend. According to Weiner (2000) the teacher plays a vital role in motivating the learners. The learner's motivation will be engaged if the motivation of the teachers is felt by the learners.

Another way on how the ALS helps the juvenile delinquents is that they protect the identity of the learner and develop the juvenile delinquent holistically leading to a positive point of view in life. The holistic development provided by the ALS is shown on the K to 12 curriculum framework (DepEd). The juvenile delinquent as a learner develops the following; i) information and media literacy, ii) learning and innovation skills, iii) effective communication skills, iv) life and career skills. For the juvenile delinquents, the most important competencies and skills should focus on life and career skills because they will help them to face the changing society and help them to reach their new goals in life.

3. What are your suggestions for the improvement of ALS program for juvenile delinquents?

Like any other programs, the alternative learning system as an education program has its own strengths and weakness points to improve. The respondents from both the rural and the urban areas suggested the following on how the implementation of the alternative learning system will be improved in order to cater effectively and successfully to the needs of the juvenile delinquent learners. First, it is crucial that additional funds for the production of quality learning materials should be allocated. To achieve the desired objectives, the ALS should be equipped with enough number of instructional materials. A respondent from the urban area explained that;

"Ang masasabi ko langtalagasanadagdagan ang fund for ALS. Fund for developing of learning materials kasigayarinsa regular school setting kahitgaanokagaling ang teachers magiging less effective kasikulang ng mga learning materials."

This suggestion was agreed upon by a respondent from the rural area;

"Sana lahat ng learning center may sapatna module, kasikadalasan sharing ng materials ang nangyayayri."

Instructional materials help in making the teaching-learning process more effective. The teaching materials can support student's learning and increase student's success. Ideally, the teaching materials will be tailored to the content in which they're being used, to the ALS learners they are being used, and the teacher. Teaching materials come in many shapes and sizes, but they all have in common the ability to support the student's learning process. 
In addition for this, the ALS instructional managers in both areas emphasized that there is no learning materials intended for juvenile delinquent learners.

"Sa mga love child ang ginagamit naming learning materials eh kung anorin ang gamit ng iba naming learners, walang specific materials generic lahat ng materials namin. Sana magkaroon ng learning materials nanaka-design talaga para sa love child learners. "

It means that the competencies that they learn are more academic-based and not for learning a competency needed by the juvenile delinquent. Because of this, it lessens the effectiveness of the instructions as well as the learning process of the juvenile delinquent. According to Foley (2001), the students in juvenile justice systems are characterized by a low to average range of intellectual functioning, fifth- to ninth-grade academic performance, significant delays in reading, math, and language, and school failure. In addition, based on the findings of a study by Nelson (2000), the nature of academic performance of this type of learner led the juvenile justice system to be described as default system. In a local setting, it can be said that the ALS in the Philippines may not be an effective tool to help the juvenile delinquents because if the instructions and competencies focused more on academics, the results will be disappointing. In similar studies, Houchins, Puckett-Patterson, Crosby, Shippen, and Jolivette (2009) found that academic-related concerns like unrealistic curriculum that fail to meet the needs of the students. A considerable lack in the student's ability or desire to engage in required tasks were seen as a major barrier to providing incarcerated youth with quality education. This is also supported by some local studies wherein there's inadequate instructional materials, equipments and simulation training (Abiog, 2011; Cusay, 2011; Caron, 2009; Villaluz, 2008).

Secondly, the instructional managers from both areas suggested that there should be additional livelihood, technical and vocational trainings.

"Gawing regular ang mga training nainibigaysa learners tulad ng mgatraining tungkolsa livelihood at yungibagalingsa TESDA kasisamga training nayun mas matutunan ng learners yungmga life skills napwedenilangmagamit for employment."

The suggestion of the instructional managers for additional livelihood, technical and vocational training in ALS is proven in a study by Cole (2002) in which the vocational and technical training involves accelerated learning. In general, learning is a complex process of acquiring knowledge, understanding, skills and values in order to be able to adapt to the changing society. Livelihood, vocational and technical training are mainly designed to lead the learners to acquire life skills, know-how and understanding that are essential in achieving their dreams and goals in life. The said suggestion may not be practiced in conventional formal education. The program responds to the needs of juvenile delinquent including social integration, crime prevention, and workforce development. Supporting this view, the participants at vocational and technical education are less 'academically sharp' and 'inadequately intelligent', the rate of return for any organized vocational and technical venture is always still very high (Bennell, 1996; Elebute \& Ohagaya, 2016) . 
Thirdly, the ALS instruction managers suggest the inclusion of gender and development to enable the juvenile delinquents to feel that they are safe and that they have hope to continue to live their life.

"yung GAD yung gender sensitive, dapatmakitarinditosa amin sa ALS para mas maramdaman ng mga students natotally ditosa ALS safe sila at marealizenila ditto sa ALS may hope namakapatuloysabuhay."

Since gender and development is one of the priorities of Sustainable Development Goals 2017, it is supported by the Department of Education by implementing the Gender Equality Movements in Schools (GEMS); a mandate which provides the students with gender responsive learning environment and various opportunities to understand gender roles and eliminate gender inequalities in school (DepEd, 2017). ALS centre is a government school and it means that they are covered under the said mandate.

Fourth, additional trainings for teachers on how to teach the loved child or the juvenile delinquents are required. The instructional managers believed that the juvenile delinquents need a different teaching style appropriate to their learning style and background. The suggestion of ALS instructional managers is supported by the study of Mathur \& Schoenfeld (2010). The ALS teachers should become an effective instructor that can stimulate students' prior learning and employ strategies that unite prior knowledge with new learning objectives. According to the findings of the study, the teachers must create a climate that promotes positive teacher-student relationships, positive peer relationships, a personal sense of self, and ability to manage emotions. At the same time, the juvenile delinquents need an instruction that focuses on social functions and that will enable them to live independently.

Lastly, the respondents suggested that there should be other different means that will measure the learning of the love child. All of the respondents agreed on this statement;

"Dapatmagkaroon din ng other form of assessment, wag puro paper and pencil test, puro multiple choice. Dapatmerong assessment kung saansa actual imemeasureyungnatutunan ng learners."

Assessment influences all aspects of students' education (Surgenor, 2010). Changes in assessment will result in changes in learning. Therefore, considerable care must be taken if reconsidering assessment practices. Since the ALS instructional managers suggest that they should utilize other means to assess the learning of the juvenile delinquents. The Department of Education should introduce the authentic assessment wherein the instructional managers may design their own assessment tools, contextualized and localized. Most of the authentic assessment focuses on life skills (King, 2000) and requiring the learners to demonstrate a range of skills related to the solution of a complex problem (DiMartino \& Castaneda, 2007) that may lead to higher chance of passing the assessment of the learning of the juvenile delinquents.

\section{Conclusion and Suggestion}


The purpose of this study is to gain an insight into ALS teachers' view on the implementation of the ALS curriculum for juvenile delinquents in both rural and urban areas in the Philippines. The interpretation and analysis of the data collected shows that the ALS teachers both from the rural and urban areas have the same experiences on the implementation of the ALS program for juvenile delinquents in terms of curriculum, instruction and assessment. The curriculum of alternative learning system has the prescribed competencies similar to those in the K to 12 curriculum. As the Department of Education changed the curriculum from Basic Education (BEC) to K to 12 curriculum, they also have to change the ALS curriculum to enable the learners to have an equal opportunity in parallel with the students from the formal education. The instruction in alternative learning system is flexible. The instructional managers may deliver the competencies in various forms and platforms like face-to-face discussion, modules, through internet, and night classes (Guerrero, 2006) which enables the juvenile delinquents to improve their capacities. In terms of assessment, there is only one form of assessment given to the learners, the A \& E test. It is in the form of paper and pencil test; limited to multiple choice type of assessment. This type of test does not measure the other aspects of learning of the juvenile learners.

The ALS teachers emphasized that once the juvenile delinquents enrol in the program, they are given a new hope and new direction in life to pursue their dreams. The instructional managers set an environment in which the learners feel that they are accepted. Through ALS, the learners are given a chance to reach their dreams in life. Lastly, the ALS teachers from both rural and urban areas have the same suggestions for the improvement of the implementation of the program. They recommend providing additional funds for the development of quality learning materials, increasing the number of learning centres, including the gender, and developing and designing various forms of assessment that will measure the other aspects of learning of the juvenile delinquents as a learner.

Based on the results of the study, it is recommended to broaden the area of comparison. Further research studies should compare the implementation of the alternative learning system at a regional level. Secondly, it is suggested to conduct an interview with the Heads of the learning centres and with the juvenile delinquents in order to determine and compare the point of views of the heads of the centres, instructional managers, and juvenile delinquents with regard to the implementation of the program. Thirdly, it is important to involve the Non-government organizations offering the ALS program to compare the implementation of the alternative learning system in the public sector and in the private sector.

\section{Conflict of Interest}

The author of the article declares no conflict of interest.

\section{Funding}

This research study was not funded by any institution. The author conducted the study on his own expenses.

\section{References}


Araneta-de Leon, R. C. (2000). Makasalanan o kapus-palad: A phenomenological study of children in conflict with the law. Philippine Journal of Psychology, 33(1).

Apao, L., Dayagbil, F., \& Abao, E. (2014). Alternative learning system accreditation and equivalency (ALS A\&E) program: Quality of life beyond poverty. International Journal of Interdisciplinary Research and Innovations, 2(4), 20-26.

Atilano, E. B., Desipeda, C. J., Domingo, Z. J., Garbin, S. N., \& Omanito, R. A. (2016). Factors influencing the dropout rate in Alternative Learning System Accreditation and Equivalency Program. The Online Journal of New Horizons in Education, 6(4), 99-109.

Bhagat, R.(2015). Juvenile Justice in Asia Pacific within a Human Rights Framework: A Case Study of India. International Journal of Education and Social Science, Vol. No.7.

National Research Council. (2013). Reforming juvenile justice: A developmental approach. National Academies Press.

Braun, V., \& Clarke, V. (2006). Using thematic analysis in psychology. Qualitative research in psychology, 3(2), 77-101.

Leicht, A., Heiss, J., \& Byun, W. J. (2018). Issues and trends in education for sustainable development (Vol. 5). UNESCO Publishing.

Carr, E. C., \& Worth, A. (2001). The use of the telephone interview for research. NT research, 6(1), 511-524.

Chappell, D., \& Lincoln, R. (2007). Abandoning identity protection for juvenile offenders. Current Issues in Criminal Justice, 18(3), 481-487.

Cho, H. (2017). Navigating the meanings of social justice, teaching for social justice, and multicultural education. International Journal of Multicultural Education, 19(2), 119.

Muñoz-Salazar, P., \& Acuña-Collado, V. (2016). Juvenile Offenders: Characteristics and Reasons Why They Drop Out of Regular Education, in Valparaiso Region. Universal Journal of Educational Research, 4(12), 2744-2749.

Underwood, L. A., Dailey, F. L., Merino, C., \& Crump, Y. (2015). Results from a MultiModal Program Evaluation of a Four Year Statewide Juvenile Sex Offender Treatment and Reentry Program. Journal of Prison Education and Reentry, 2(2), 1932.

Department of Education (2016). Press released. Isang Daan, Isang DepEd toward education for all from http://www.deped.gov.ph/press-releases/isang-daan-isang-deped-towardeducation-all

Department of Education (2016). Press released. Age Does Not Matter: DepEd 2017 Proposed Budget Seeks to Hasten ALS Expansion from http://www.deped.gov.ph/press-releases/age-does-not-matter-deped-2017-proposedbudget-seeks-hasten-als-expansion

DiMartino, J., \& Castaneda, A. (2007). Assessing applied skills. Educational Leadership, 64(7), 38-42.

Francisco, K. (2016). PNP: Quezon City has highest number of index crimes. Rappler. Retrieved, 19. 
Guerro, C. S. (2006) Alternative Learning System. Teacher Induction Program. Department of Education. Module 2.2.

Jabbarifar, T. (2009, November). The importance of classroom assessment and evaluation in educational system. In Proceedings of the 2nd International Conference of Teaching and Learning (pp. 1-9).

Johnson, S.M., Rosch, J. (2010) Juvenile or Adult Court: Research on Future Offending. Center for Child and Family Policy, Duke University. pp. 21-24

King, R. M. (2000). Portfolio development: Using authentic learning assignments in psychology courses. North American Journal of Psychology, 2(1), 151-166.

Elebute, A., \& Shagaya, O. M. (2016). Impact of Vocational and Technical Education on Livelihood Sustenance and Economic Development in Nigeria: The Art Workshop Experience. International Journal of Vocational and Technical Education Research, 2(2), 15-35.

McDavid, J. W., \& McCandless, B. R. (1962). Psychological theory, research, and juvenile delinquency. J. Crim. L. Criminology \& Police Sci., 53, 1.

Mercado, I. P. (2015). Problems encountered in the alternative learning system in Tanauan City. International Journal of Education and Social Science, 6. 2(8), 38-43.

Moskalenko, M. R., Dorozhkin, E. M., Ozhiganova, M. V., Murzinova, Y. A., \& Syssa, D. O. (2016). Peculiarities of Students of Pedagogical Specialties Training in Preventive work with Juveniles Delinquents. International Journal of Environmental and Science Education, 11(16), 8810-8820.

Soriano Y.(2001) The Problem of Youth Offenders: When Children Commit Adult Crimes. Bulatla, $t$ Issue no. 36 , p.21- 27.

Villaluz, Reynaldo D.(2008). Factors Affecting the Achievement of Completers in the Alternative Learning System Program in the Province of Laguna, Technological Institute of the Philippines, Manila, Dissertation.

Weiner, B. (2001). Intrapersonal and interpersonal theories of motivation from an attribution perspective. In Student motivation (pp. 17-30). Springer, Boston, MA.

Yang, S. (2015). Evaluation of the Intervention and Rehabilitation Program in Residential Facilities and Diversion Programs for Children in Conflict with the Law. Universalia, 245 Victoria Ave. Quebec, Canada. www.universalia.com 